\title{
覓
}

\section{THE ROLE OF SALICYLIC ACID AND PSEUDOMONAS FLUORESCENS IN SYSTEMIC RESISTANCE AGAINST RHIZOCTONIA SOLANI KÜHN IN GUAR (CYAMOPSIS TETRAGONOLOBA (L.) TAUB.)}

\author{
Montaser F. Abdel-Monaim* \\ Plant Pathology Research Institute, Agriculture Research Center, Giza, Egypt.
}

\begin{abstract}
A B S T R A C T
Rhizoctonia solani was found to be associated with root rot symptoms of guar plants collected from different fields in New Valley governorate, Egypt. All the obtained isolates were able to attack guar plants (cv. Local) causing damping-off and root rot diseases. $R$. solani isolates No. 8 (RG8) was the more virulent ones in the pathogenicity tests. Salicylic acid (SA) and Pseudomonas fluorescens (PF) individually or in combination were examined for their potential in suppression damping-off and root rot and growth promotion of guar plants in vitro and in vivo. Both SA and P. fluorescens either individually or in combination inhibited the growth of the tested pathogenic fungi.SA combined with $P$. fluorescens recorded the highest inhibited growth followed by P. fluorescens alone. Under greenhouse and field conditions, all treatments significantly reduced damping-off and root rot severity. The combination of SA and $P$. fluorescens was more effective than using them individually. Under field conditions, all these treatments significantly increased growth parameters (plant height and No. of branches plant-1) and yield components (No. of pods plant-1, weight of 100 seeds and total yield fed.-1 and Guaran content (gm plant-1) in both locations (El-Kharga and Mallawy Agric. Res. Stations) during growing season 2014.The combination of SA and P. fluorescens were recorded the highest growth parameters and yield components. Generally, the combination of SA and $P$. fluorescens recorded the best results for controlling damping-off and root rot diseases in greenhouse and field with addition improved plant growth and increased yield components in the field. In physiological studies, activity of defense-related enzymes, including peroxidase (PO), polyphenol oxidase (PPO), phenylalanine ammonia lyase (PAL), pathogenesis related (PR) protein (chitinase and $\beta 1,3$ gluconase), were increased in inoculated and non-inoculated plants treated with the SA and P. fluorescens either individually or in combination, during the experimental period. The combination of SA and $P$. fluorescens recorded the highest increase in activity of all enzymes. In general, the activity of these enzymes begins to accumulate after two days of treatment and reached maximum levels at 6 to 10 days, then the activities of these enzymes were decreased progressively. On the other hand, total phenols and lignin increased in guar plants inoculated with $R$. solani and treated with SA and P. fluorescens individually or in combination. The highest accumulation of phenols was recorded $8^{\text {th }}$ days from application, while lignin recorded the highest level at $10^{\text {th }}$ days from application. In the end, these results suggested that SA and P. fluorescens either individually or in combination may play an important role in controlling the guar damping-off and root rot diseases, though they have induction of systemic resistance in guar plants.
\end{abstract}

Keywords: Guar, Damping-off and root rot, Salicylic acid, P. fluorescens, Growth and yield parameters, defense-related enzymes.

\section{INTRODUCTION}

Guar or cluster bean (Cyamopsis tetragonoloba (L.) Taub.) belongs to the family Fabaceae (Leguminaceae) (Gillet, 1958), is a coarse, upright, bushy, a drought tolerant summer annual legume and it is cultivated as a feed crop

* Corresponding Author:

Email: fowzy_2008@ yahoo.com

(C) 2017 ESci Journals Publishing. All rights reserved. for human and livestock consumption. It is grown principally as a seed crop for export and as a vegetable crop for the local market in Pakistan. It is grown in tropical Asia, Africa and America. The major world suppliers are India, Pakistan and the United States, with smaller acreages in Australia and Africa (Undersander et al., 2006). Guar is commercially grown for its seeds as a source of natural polysaccharide (galactomannan), 
commercially known as guar gum. Guar gum has a number of uses in food (Khalil, 2001) and other industries, such as paper, textiles, oil well drilling and pharmaceuticals and a well-known traditional plant used in folklore medicine. It acts as an appetizer, cooling agent, digestive aid, laxative, and is useful in dyspepsia and anorexia Anti-ulcer, anti-secretory, cytoprotective, hypoglycemic, hypolipidemic and anti-hyperglycemic effects (Mukhtar et al., 2006). In addition, Guar beans are potentially high sources of additional phytochemicals (Wang and Morris, 2007).

Guar is known to suffer many diseases which are responsible for its quality and low yield resulting in severe economic losses to the country as it is an important cash crop with a great potential for foreign exchange (Mohamed et al., 2006 and Pareek and Varma, 2014). The major disease causing low planting value of the crop includes fungal, bacterial and viral diseases. Among the different pathogens attacking the crop. Rhizoctonia solani is the most common fungus causing considerable yield losses (Matloob and Juber 2013). The pathogen caused damping-off diseases in the seedlings stages. At later stages of plant growth, the infected plants exhibit rot near the soil which results in wilting of the host plant (Pareek and Varma, 2014).

Although the application of fungicides is far the most effective method to control guar damping-off and root rot diseases, it can be involved in many problems due to health risk concerns and environmental pollution. Thus, there is a growing need to develop alternative approaches for the management of this pathogen. An acceptable approach that is being actively investigated involves the use of plant growth promoting rhizobacteria such Pseudomonas fluorescens and bioactive substances such salicylic acid in controlling soil borne fungi (Rajkumar et al., 2008 and Couillerot et al., 2009 and Abdel-Monaim, 2013).

Salicylic acid (SA) has been found to be active as antimicrobial agents in various trials as disease resistance inducers. These have been reported for inducing resistance against several plant pathogens, i.e. TMV (Marrero et al., 1990), bacterial soft (El-Sayed, 1996), bacterial wilt (Abdel-Said et al., 1996) as well as soil borne fungal root rot and wilt diseases (Rajkumar et al., 2010 and Abdel-Moaniam, 2013). Moreover, few attempts proved the direct inhibitory effect of SA on the growth of phytopathogenic microorganisms (El-Mougy, 2002 and 2004).
On the other hand, the application of biological control using antagonistic microorganisms proved to be successful for controlling various plant diseases in many countries. Biological control is proposed to be an effective and non-hazardous strategy to reduce crop damage caused by plant pathogens. In recent years the $P$. fluorescens has been extensively used for plant growth promotion and disease control (Tabarraei et al., 2011). Biological control of soil borne pathogens is often attributed to improved nutrition that boosts host defenses or to direct inhibition of pathogen growth and activity.

Similarly, SA amendment was tested in combination with biocontrol agents. Saikia et al. (2003) tested the efficiency of Pseudomonas fluorescens with or without SA amendment in chickpea against Fusarium wilt infection. The application of $P$. fluorescens (pf4-92) with SA recorded the highest protection of chickpea seedlings against wilting.

The present study is planned to evaluate the efficiency of SA and Pseudomonas fluorescens when used as individually or in combination as safe control means in controlling damping-off and root rot diseases in guar.

\section{MATERIAL AND METHODS}

Isolation and Identification of Rhizoctonia solani: $R$. solani was isolated from guar plants shown necrotic lesions on root and hypocotyls, collected from fields in New Valley Governorate. Small pieces of infected root and hypocotyls were surface sterilized with $0.5 \%$ sodium hypochlorite for 1 minute, rinsed with sterile distilled water and plotted dry. The pieces were placed on potato glucose agar (PGA) medium containing 50 $\mathrm{mg} / \mathrm{L}$ of streptomycin sulfate in Petri plates of $9 \mathrm{~cm}$ in diam. The plates were maintained at $25^{\circ} \mathrm{C}$ for $48-72 \mathrm{hrs}$. Fungal hyphae from the margin of developing colonies were transferred into PDA slants. $R$. solani isolates were identified on the basis of hyphal characteristics (Sneh et al., 1996). Identification was confirmed by Assiut University Mycological Centre (AUMC), Assiut University, Assiut, Egypt. The obtained isolates were maintained on PDA slants and kept in a refrigerator at 5 ${ }^{\circ} \mathrm{C}$ for further study.

Pathogenicity of Rhizoctonia solani isolates: The pathogenicity tests of Rhizoctonia solani isolates were carried out at New Valley Agric. Res. Station, on local guar cultivar in pots containing soil infested with the obtained isolates individually using homogenized culture technique according to Muthomi et al. (2007). 
Preparation of the fungal inocula: The inocula of the obtained isolates were prepared from one week old culture grown on $50 \mathrm{~mL}$ potato glucose broth (PDB) medium in the conical flask $(250 \mathrm{~mL})$ and incubated at $25 \pm 1{ }^{\circ} \mathrm{C}$. The content of the flask was homogenized in a blender for one min. Plastic pots were filled with sterilized soil and mixing with fungal inocula at rate 100 $\mathrm{mL}$ homogenized culture per pot $(30 \mathrm{~cm}$ in diam.), seven days before planting. Five pots were used as replicates per isolate and another 5 pots with an equal amount of sterile PDB medium without fungal inoculation were severed as a control. Five sterilized surface seeds were sown in each pot. Percentage of damping-off was recorded 30 days after planting. While severity of root rot was determined after 90 days using a rating scale of 0 to 5 on the basis of root discoloration or leaf yellowing as follows: 0, neither root discoloration nor leaf yellowing; $1=$ from $<0$ to $25 \%$ root discoloration or one leaf yellowed; $2=$ from $<25$ to $50 \%$ root discoloration or more than one leaf yellowed; $3=$ from $<5$ o to $75 \%$ root discoloration plus one leaf wilted; $4=$ up to $75 \%$ root discoloration or more than one leaf wilted; and 5, completely dead plants. For each replicates a disease severity index (DSI) similar to that one described by Liu et al. 1995 was calculated as follows:

$$
\text { DS }=\Sigma \mathrm{d} /(\mathrm{d} \max \times \mathrm{n}) \times 100
$$

Where $d$ is the disease rating possible, $d$ max is the maximum disease rating and $n$ is the total number of plants examined in each replicate.

Isolation and in-vitro screening of Pseudomonas fluorescens against $R$. solani pathogen

Isolation of fluorescent pseudomonads: Fluorescent pseudomonads were isolated from the rhizosphere of guar grown in an agriculture field at El-Kharga, New Valley governorate as detailed by Rajkumar et al. (2005). Fluorescence of the colonies under UV light was taken as the primary criterion for selection of the isolates.

Screening of fluorescent pseudomonads: Dual culture technique was used to evaluate the antagonistic activity of P. fluorescens based on Yoshida et al., 2001 and the best one was selected for future studies.

Efficacy of SA and P. fluorescens against Rhizoctonia solani

In vitro studies: The effect of chemical inducers (SA) and plant growth promoting rhizobacteria ( $P$. fluorescens) individually and/or in combination against $R$. solani was studies as follows:
A) Chemical Inducer (SA): The effect of chemical inducer (SA) on the growth of R. solani was evaluated in PDA medium. $20 \mathrm{ml}$ of PDA medium containing $1 \mathrm{mM} \mathrm{SA}$ (Abdel-Monaim, 2013) was poured in the plates and inoculated with the pathogenic fungi as above.

B) Antagonistic Biocontrol Agents: Pseudomonas fluorescens was streaked at opposite ends of PDA plates near the edge and incubated at $25 \pm 1^{\circ} \mathrm{C}$ for $24 \mathrm{hr}$. Then a mycelial disc $(5 \mathrm{~mm})$ of the tested fungus was placed in the center of each plate as above.

C) The combination between of SA and P. fluorescens: Flasks (250 ml) containing $200 \mathrm{ml}$ PDA medium were amended with $1 \mathrm{mM}$ SA then each flask was poured in10plates.Theseplateswereinoculatedwith antagonistic isolate and pathogenic isolates as before. For control treatment, the agar plug of only $R$. solani was placed on PDA plates. The inoculated plates incubated at $25 \pm 1{ }^{\circ} \mathrm{C}$ until a colony of control grew to full plate. At this point, colony diameter was measured using a ruler. Percentage of growth inhibition of pathogen was calculated using the formula below:

$$
\% \text { Inhibition }=(A-B) / A \times 100
$$

Where:

$\mathrm{A}=$ Colony diameter of pathogen in control $\mathrm{B}=$ Colony

diameter in treated plates

\section{In vivo studies}

Greenhouse Experiments: The effects of salicylic acid (SA) and Pseudomonas fluorescens (PF) as plant growth promoting rhizobacteria individually or in combination against guar damping-off and root rot diseases incited by $R$. solani were evaluated under greenhouse conditions. SA was prepared as solutions at $1 \mathrm{mM}$. A cell suspension of $P$. fluorescens grown on nutrient broth medium for 3 days at $25 \pm 1{ }^{\circ} \mathrm{C}$ was adjusted to $2.5 \times 10^{8}$ $\mathrm{CFU} / \mathrm{mL}$ (Abdel-Monaim, 2013). The in combination between SA and P. fluorescens prepared with dissolving chemical inducers in suspension of $P$. fluorescens. Guar seeds soaked for $6 \mathrm{hr}$. in the following treatments: $1=\mathrm{SA}$ $(1 \mathrm{mM}) ; 2=P$. fluorescens $\left(2.5 \times 10^{8} \mathrm{CFU} / \mathrm{mL}\right) ; 3=\mathrm{SA}+P$. fluorescens; and $4=$ control. Plastic pots were filled with sterilized soil and mixed with $R$. solani (isolate RG 8) inocula at rate $100 \mathrm{~mL}$ homogenized culture per pot, seven days before planting, then sown by 5 seeds of each treatment. Five replicates were used for each treatment. In control treatment, guar seeds soaked in water for 6 hr. and sown the same rate. Pots were irrigated as needed. All pots were examined after 30 and 90 days to record the percentage of damping-off and root rot 
severity as above, respectively. Also, the survival plants were calculated.

Field experiments: Field experiment was carried out at El-Kharga Res. Station Farm, New Valley governorate and Mallawy Res. Station Farm, El-Minia governorate during summer 2014 growing season, to evaluate the efficiency of the tested chemical inducers (SA) and P. fluorescens individually or in combination for controlling dampingoff and root rot diseases and its effect on growth and yield parameters under field conditions. The experimental design was a complete randomized block with three replicates. The experimental unit area was $10.5 \mathrm{~m}^{2}$ (3.5 $\times$ $3 \mathrm{~m}$ ). Each unit included 5 rows; each row was $3.5 \mathrm{~m}$ in length and $60 \mathrm{~cm}$ width. Guar seeds (cv. local) were soaked in treatments described above for $6 \mathrm{hr}$. The seeds treated were sown in hills $25 \mathrm{~cm}$ apart on one side of the row, 2 seed per hill. In control treatment, guar seeds were soaked in water for $6 \mathrm{hr}$. and sown at the same rate. The normal cultural practices of growing guar were followed. Percentages of damping-off and root rot severity were recorded 30 and 90 days after sowing. At harvest, plant height $(\mathrm{cm})$, number of branches plant ${ }^{-1}$, number of pods plant ${ }^{-1}$, Guaran content (gm plant ${ }^{-1}$ ) and, 100-seed weight and total yield $\left(\mathrm{kgfed}^{-1}\right)$ were measured. Guaran content (gm plant ${ }^{-1}$ ) in seeds was recorded using the method Anderson (1949).

Biochemical changes associated with SA and $P$. fluorescens treatment: To detect the accumulation of peroxidase (PO), polyphenol oxidase (PPO), phenylalanine ammonia lyase (PAL) and pathogenesis related protein (Chitinase and $\beta$-1,3-glucanase) and content each of phenolic compounds and lignin, 15 days old seedlings were injected with SA (1 mM), P. fluorescens $\left(2.5 \times 10^{8} \mathrm{CFU} / \mathrm{mL}\right), \mathrm{SA}+P$. fluorescens and sterilized distilled water (SDW), $50 \mu$ plant $^{-1}$. After 2 days from treatment plants, pot soils infested were inoculated with $100 \mathrm{ml}$ of $R$ solani (isolate RG8) homogenate suspension per pot. The following treatments were made (i) controltreated with SDW only; (ii) pathogen control- treated with R. solani; (iii) plant treated with $\mathrm{SA}$;(iv) plant treated with $P$. fluorescens; (v) plant treated with $\mathrm{SA}+P$. fluorescens; (vi)plant treated with $\mathrm{SA}$ and after 2 days inoculated with the pathogen (vii) plant treated with $P$. fluorescens and after2 days inoculated with the pathogen(viii) plants treated with $\mathrm{SA}+P$. fluorescens and after 2 days inoculated with the pathogen. The peroxidase (PO), polyphenol oxidase (PPO), phenylalanine ammonia lyase (PAL), chitinase and $\beta$-1,3-glucanase activities and content each of phenolic compounds and lignin were estimated after $0,2,4,6,8$ and 10 days from inoculation. One gram of plant tissue was homogenized in $10 \mathrm{ml}$ of icecold $50 \mathrm{mM}$ potassium phosphate buffer $(\mathrm{pH}$ 6.8) containing $1 \mathrm{M} \mathrm{NaCl}, 1 \%$ polyvinylpyrrolidone, (PVP), 1 $\mathrm{mM}$ Ethylenediaminetetraacetic acid (EDTA) and $10 \mathrm{mM}$ $\beta$-mercaptoethanol (Biles and Martyn, 1993). After filtration through cheesecloth, the homogenates were centrifuged at $8000 \mathrm{rpm}$ at $4^{\circ} \mathrm{C}$ for $25 \mathrm{~min}$. The supernatants (crude enzyme extract) were stored at $-20^{\circ} \mathrm{C}$ or immediately used for determination PO, PPO, $\mathrm{PAL}$, chitinase and $\beta$-1,3-glucanase enzymes activities and total protein. In the case of every enzyme under investigation, each treatment consisted of four replicates (3 plants/ replicate) and two spectrophotometric readings using Milton Roy Spectrophotometer (Milton Roy spectronic1201) were taken per replicate. The experiment for bioassays was repeated twice in time.

Peroxidase activity: The enzyme activity of PO was determined a direct spectrophotometrically method (Hammerschmidt et al., 1982) using guaiacol as a common substrate for peroxidases. The reaction mixture consisted of $0.2 \mathrm{ml}$ crude enzyme extract and $1.40 \mathrm{ml}$ of a solution containing guaiacol, hydrogen peroxide $\left(\mathrm{H}_{2} \mathrm{O}_{2}\right)$ and sodium phosphate buffer $(0.2 \mathrm{ml} 1 \%$ guaiacol $+0.2 \mathrm{ml}$ $1 \% \mathrm{H}_{2} \mathrm{O}_{2}+1 \mathrm{ml} 10 \mathrm{mM}$ potassium phosphate buffer), was incubated at $25^{\circ} \mathrm{C}$ for $5 \mathrm{~min}$ and the initial rate of increase in absorbance was measured over $1 \mathrm{~min}$ at $470 \mathrm{~nm}$ using spectrophotometer. Peroxidase activity was expressed as units of $\mathrm{PO} / \mathrm{mg}$ protein (Urbanek et al., 1991).

Polyphenol oxidase activity: The activity of PPO was determined by adding $50 \mu \mathrm{l}$ of the crude extract to $3 \mathrm{ml}$ of a solution containing $100 \mathrm{mM}$ potassium phosphate buffer, pH 6.5 and $25 \mathrm{mM}$ pyrocatechol. The increase in absorbance at $410 \mathrm{~nm}$, for $10 \mathrm{~min}$ at $30^{\circ} \mathrm{C}$, was measured (Gauillard et al., 1993). One PPO unit was expressed as the variation of absorbance at $410 \mathrm{~nm}$ per milligram of soluble protein per minute.

Phenylalanine ammonia-lyase activity: Phenylalanine ammonia-lyase (PAL) activity was determined following the direct spectrophotometric method adapted by Cavalcanti et al. (2007). Two hundred microlitres of the crude enzyme extract previously dialyzed overnight with 100 mM Tris- HCl buffer, pH 8.8, were mixed to obtain a solution containing $200 \mu \mathrm{l} 40 \mathrm{mM}$ phenylalanine, $20 \mu \mathrm{l} 50$ $\mathrm{mM} \beta$-mercaptoethanol and $480 \mu \mathrm{l} 100 \mathrm{mM}$ Tris- $\mathrm{HCl}$ buffer, $\mathrm{pH}$ 8.8. After incubation at $30^{\circ} \mathrm{C}$ for $1 \mathrm{~h}$, the reaction stopped by adding $100 \mu \mathrm{l} 6 \mathrm{~N} \mathrm{HCl}$. Absorbance at 
$290 \mathrm{~nm}$ was measured and the amount of trans-cinnamic acid formed was evaluated by comparison with a standard curve (0.1-2 mg trans-cinnamic acid/ml) and expressed as units of PAL min ${ }^{-1} \mathrm{mg}_{\text {protein }}{ }^{-1}$.

Chitinase activity: The chitinase activity was determined using the method described by Wirth and Wolf (1992). High polymeric carbomethyl-substituted chitin labelled covalently Remazol Brilliant Violet 5R (CM-Chitin*-RBV. Comp. Loewe Biochemica) was used as the substrate. The reaction mixture was as follows: 0.50 ml $0.01 \mathrm{M} \mathrm{Na-Acetate} \mathrm{buffer} \mathrm{pH} 5.2$ with $5 \%(\mathrm{v} / \mathrm{v})$ glycerin, $0.25 \mathrm{ml}$ plant extract and $0.25 \mathrm{ml}$ dye labeled substrate $\mathrm{CM}-{ }^{*} \mathrm{RBV}$ solution $(2 \mathrm{mg} / \mathrm{ml})$. Test samples were incubated in a water bath at $37^{\circ} \mathrm{C}$ for $120 \mathrm{~min}$. The enzyme reaction was terminated by adding $0.25 \mathrm{ml} 2 \mathrm{~N}$ $\mathrm{HCl}$. After centrifugation (8000 rpm; $25 \mathrm{~min})$, supernatants containing soluble, dye labelled degradation products were transferred to cuvet. Absorbency was measured spectrophotometrically at $550 \mathrm{~nm}$, sodium acetate buffer was added to blanks instead of plant extract. Enzyme activity was expressed as enzyme unit/mg protein.

$\boldsymbol{\beta}-1,3$-glucanase activity: $\beta$-1,3-glucanase activity was assayed by the laminarin-dinitro salicylic acid method (Pan et al., 1991). Root samples (1 g) were extracted with $2 \mathrm{~mL}$ of $0.05 \mathrm{M}$ sodium acetate buffer ( $\mathrm{pH} 5.0$ ) and centrifuged at $16000 \mathrm{~g}$ for $15 \mathrm{~min}$ at $4{ }^{\circ} \mathrm{C}$. The supernatant was used in the enzyme assay. The reaction mixture consisted of $62.5 \mu \mathrm{L}$ of $4 \%$ laminarin and $62.5 \mu \mathrm{L}$ of enzyme extract. The reaction was carried out at $40{ }^{\circ} \mathrm{C}$ for $10 \mathrm{~min}$. The reaction was then stopped by adding $375 \mu \mathrm{L}$ of dinitro salicylic acid and heating for 5 min on boiling water, vortexed and its absorbance was measured at 500 $\mathrm{nM}$. The enzyme activity was expressed as $\mu \mathrm{g}$ glucose released $\mathrm{min}^{-1} \mathrm{mg}^{-1}$ protein.

Protein concentration: Total protein content of the samples was quantified according to the method described by Bradford (1976).

Determination of phenolic compounds: To assess phenolic content, $1 \mathrm{~g}$ fresh plant sample was homogenized in $10 \mathrm{ml} 80 \%$ methanol and agitated for 15 $\mathrm{min}$. at $70 \stackrel{\circ}{ } \mathrm{C}$. One $\mathrm{ml}$ of the extract was added to $5 \mathrm{ml}$ of distilled water and $250 \mu \mathrm{l}$ of $1 \mathrm{~N}$ Folin-Ciocalteau reagent and the solution was kept at $25^{\circ} \mathrm{C}$. The absorbance was measured with a spectrophotometer at $725 \mathrm{~nm}$. Catechol was used as a standard. The amount of phenolic content was expressed as phenol equivalents in $\mathrm{mg} \mathrm{g}^{-1}$ fresh tissue (Saikia et al., 2006).
Determination of lignin: One gram plant tissue from each treatment was mixed with $10 \mathrm{~g}$ of trichloroacetic acid (TCA) and incubated at $90{ }^{\circ} \mathrm{C}$. Delignification was stopped by cooling the reaction mixture after $240 \mathrm{~min}$. of reaction time. The reaction vessel was immersed in cold water and $5 \mathrm{ml}$ of cold acetone were added. The suspension was filtered and liquor was evaporated until dark, high consistency liquid without the smell of acetone was obtained. Lignin was precipitated by pouring the liquid into $200 \mathrm{ml}$ cold water. Lignin was filtered and washed with warm water several times. After that, lignin was air-dried overnight at $4{ }^{\circ} \mathrm{C}$ then weight (Liken and Perdih, 1999).

Statistical analysis: Analyses of variance were carried out using MSTATC, 1991 program ver. 2.10 (Freed, et al., 1991). The least significant difference was employed to test for significant difference between treatments at $p \leq$ 0.05 (Gomez and Gomez (1984).

\section{RESULTS}

Isolation trails from rotted plants collected from different locations of New Valley governorates exhibited the isolation of nineteen fungus isolates which were identified as Rhizoctonia solani.

Results illustrated in Figure 1 shows that all the obtained isolates able to attack guar plants caused damping-off and root rot diseases with various degrees. $R$. solani isolate RG 7 and 8 caused the highest damping-off (50\%) followed by isolates RG15 (45\%). Isolates RG2, RG3, 10, 12, 13, 18 and 19 were the weak ones for cause damping-off (5\%). Also, all R. solani isolates able to attack guar plant in the late stage of growth causing root rot symptoms with various degrees. $R$. solani isolates RG2 recorded the highest root rot severity (55.25\%) followed by RG4, RG14 and RG8 (45.26 and $47.25,43.36 \%$, respectively). While $R$. solani isolates RG10, 18 and 19 recorded the lowest root rot severity (6.33, 4.56 and $6.35 \%$ respectively). Generally, $R$. solani isolates RG8 followed by RG2 were more aggressive for attack guar plant than the other isolates.

Effect of SA and P. fluorescens on Radial Growth of rate $R$. solani: Data in Figure 2 reveal that SA and $P$. fluorescens either individually or in combined have significantly reduced the linear growth of all tested fungi. In general, the combination between of SA and $P$. fluorescens was more effective than any of them individually. On the other hand, P. fluorescens was able to inhibit the growth of $R$. solani more than SA.

Effect of salicylic acid and $P$. fluorescens against damping-off and root rot diseases caused by $R$. solani 
in pots under greenhouse conditions: Data shown in Figure 3 clearly indicate that both treatments (SA and $P$. fluorescens) either applied individually or in combination have significantly reduced damping-off and root rot diseases caused by $R$. solani isolate RG2 compared with the untreated control plants under greenhouse conditions. The combination between SA and $P$.

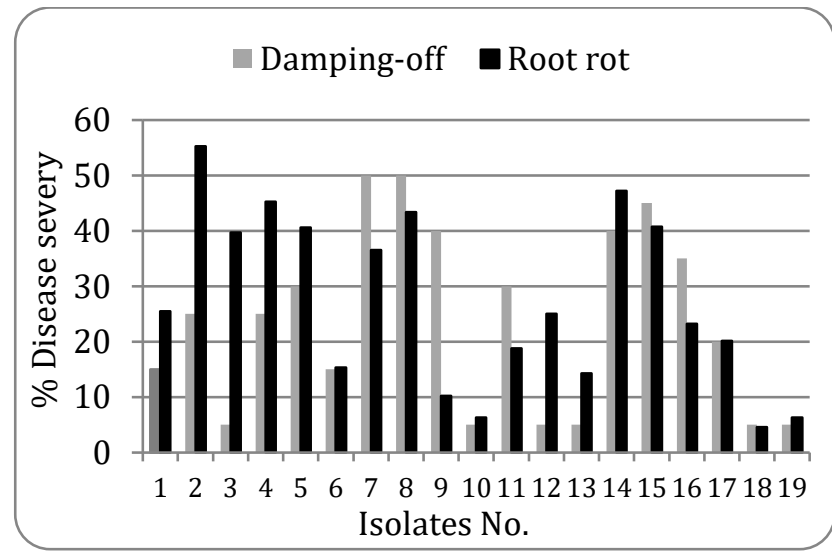

Figure 1. Pathogenicity tests of Rhizoctonia solani isolated from natural diseased guar plants.

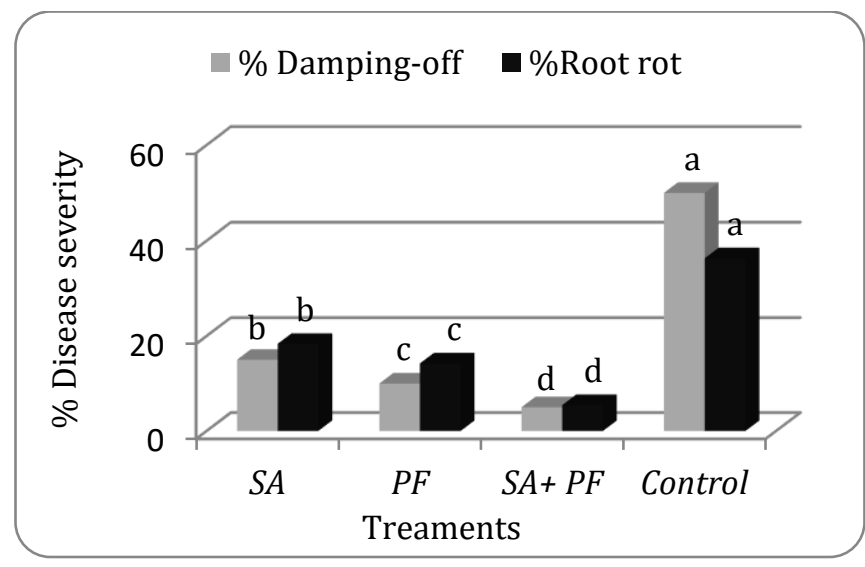

Figure 3. Effect of salicylic acid (SA) and Pseudomonas fluorescens $(\mathrm{PF})$ individually or in combination against damping-off and root rot diseases under artificial infection by R. solani (RG2), under greenhouse conditions.

Effect of salicylic acid and $P$. fluorescens against damping-off and root rot diseases under field conditions: Data are presented in Figure 4 and 5 showed that all treatments (SA and P. fluorescens individually or in combination) had significantly protected guar plants against $R$. solani pathogen as compared to the untreated control in both locations during summer season 2014.The fluorescens recorded the highest reduction of damping-off and root rot severity compared with used of them individually. In fact, this treatment reduced damping-off disease from $50 \%$ in control to $5 \%$ and reduces root rot severity from $36.35 \%$ in control to $5.47 \%$. On the other hand, $P$. fluorescens was more effective in reduced damping-off and root rot diseases than SA treatment.

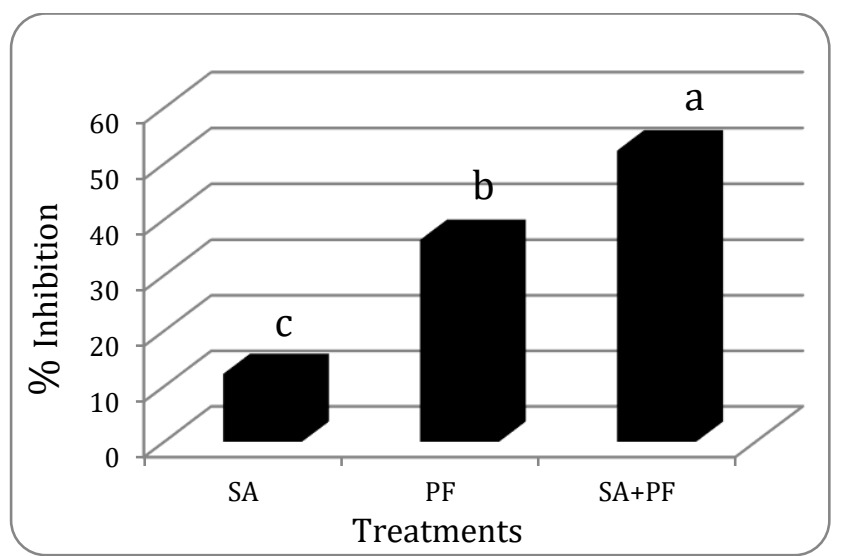

Figure 2. Effect of SA and P. fluorescens individually or combined on the growth of $R$. solani in vitro.

efficiency of combination between SA and P. fluorescens were more effective for controlling damping-off and root rot diseases than applied $P$. fluorescens or SA individually in both locations. Where decreased damping -off from 45 and $25.59 \%$ in control to 6.35 and $4.29 \%$ and reduced root rot severity from 30.58 and $35.69 \%$ in control to 6.59 and $12.34 \%$ in El-Kharga and Mallawy, respectively. On the other hand, $P$. fluorescens was more effective for controlling damping-off and root rot severity than SA in El-Kharga. In contrary SA was more effective than $P$. fluorescens in Mallawy. Generally, all treatments were highly effective for controlling damping-off and root rot diseases in El-Kharga than Mallawy except SA in case of damping-off severity.

Effect of SA and $P$. fluorescens on guar growth and yield parameters: All of the tested treatments viz. $P$. fluorescens and SA individually or in combination significantly increased growth and yield parameters in treated guar plants i.e. plant height and number of branches plant ${ }^{-1}$, number of pods plant ${ }^{-1}$ Guaran content (gm plant ${ }^{-1}$ ), seed index and total yield (Kg fed-1) comparison with those of check treatment in both locations during growing season 2014 (Table 1). In this respect, the applied of combination P. fluorescens and SA 
were most effective than apply any of the treatments alone. Moreover, using combined P. fluorescens and SA improved plant height from 113.37 and $105.30 \mathrm{~cm}$ in check control treatment to 156.38 and $145.22 \mathrm{~cm}$ and

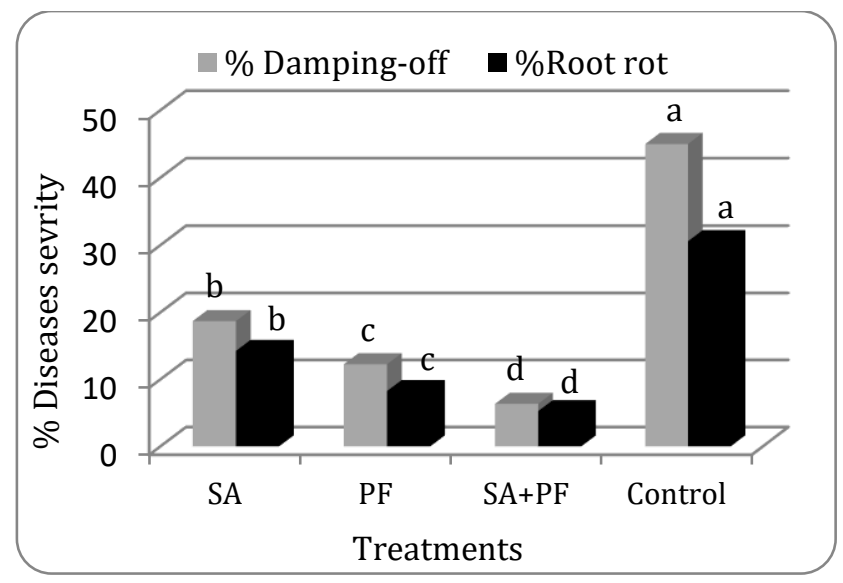

Figure 4. Effect of salicylic acid (SA) and Pseudomonas fluorescens (PF) individually or in combination against damping-off and root rot diseases grown in a naturally infested soil (open field conditions) in El-Kharga Research Station, New Valley. increased number of branch plant ${ }^{-1}$ from $8.33,10.67$ to $12.03,16.26$ and increased number of pods plant ${ }^{-1}$ from $143.33,122.32$ in control to 220.75, 211.40 in both locations, respectively.

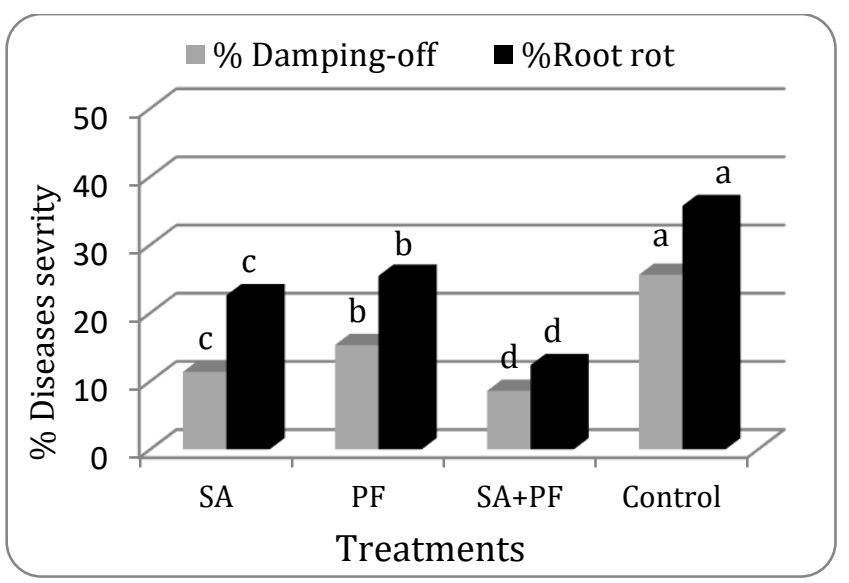

Figure 5. Effect of salicylic acid (SA) and Pseudomonas fluorescens $(\mathrm{PF})$ individually or in combination against damping-off and root rot diseases grown in a naturally infested soil (open field conditions) in Mallawy Agric. Res. station, El- Minia.

Table 1. Effect of SA and P. fluorescens individually or in combination on growth and yield parameters of guar plants grown under field condition in El-Kharga and Mallawy Agric. Res. Station during growing season 2014.

\begin{tabular}{lcccccc}
\hline Treatments & $\begin{array}{c}\text { Plant } \\
\text { height }\end{array}$ & $\begin{array}{c}\text { No. of branches } \\
\text { plant }^{-1}\end{array}$ & $\begin{array}{c}\text { No. of pods } \\
\text { plant }{ }^{-1}\end{array}$ & $\begin{array}{c}\text { Guaran content } \\
\text { (gm plant }\end{array}$
\end{tabular}

Different letters indicate significant differences among treatments within the same column according to least significant difference test $(\mathrm{P} \leq 0.05)$.

On the other hand, P. fluorescens recoded highly increased in all growth and yield parameters in El-Kharga Res. Station than SA, but these results were reflected in Mallawy Agric. Res. Station where SA was more effective than P. fluorescens in this respect.

Biochemical changes associated with $S A$ and $P$. fluorescens treatments: Accumulation of peroxidase
(PO), polyphenol oxidase (PPO), phenylalanine ammonia lyase (PAL) enzymes, and pathogenesis related (PR) protein (chitinase and $\beta-1,3$ glucanase), phenolic compounds and lignin in plants inoculated with $R$. solani or non-inoculated plants treated and untreated with $P$. fluorescens and SA individually or in combination were studied. 
Peroxidase activity: Data in Figure 6 show that PO activity of inoculated and non-inoculated guar plants treated with SA, P. fluorescens and SA $+P$. fluorescens was higher than that of untreated plants after all time from the application. Inoculated plants caused the highly PO activity than non-inoculated plants whether treated and untreated especially after 4 days from treatment any treatments except plant treated with SA and inoculated wilt $R$. solani. The combination between $P$. fluorescens and SA recorded the high enzyme activity than $P$. fluorescens or SA individually either in plant inoculated or noninoculated. The highest levels of PO were determined 8 days after treatment in all cases. The highest of $\mathrm{PO}$ activity was recorded in guar plants inoculated with the pathogen and treated with $P$. fluorescens and SA at $10^{\text {th }}$ day from the application (2.458 enzyme unit $\mathrm{mg}^{-1}$ protein $\mathrm{min}^{-1}$ ). In general, the enzyme activity rapid increase in the activity of defense related components until 10 days after application then decreased progressively.

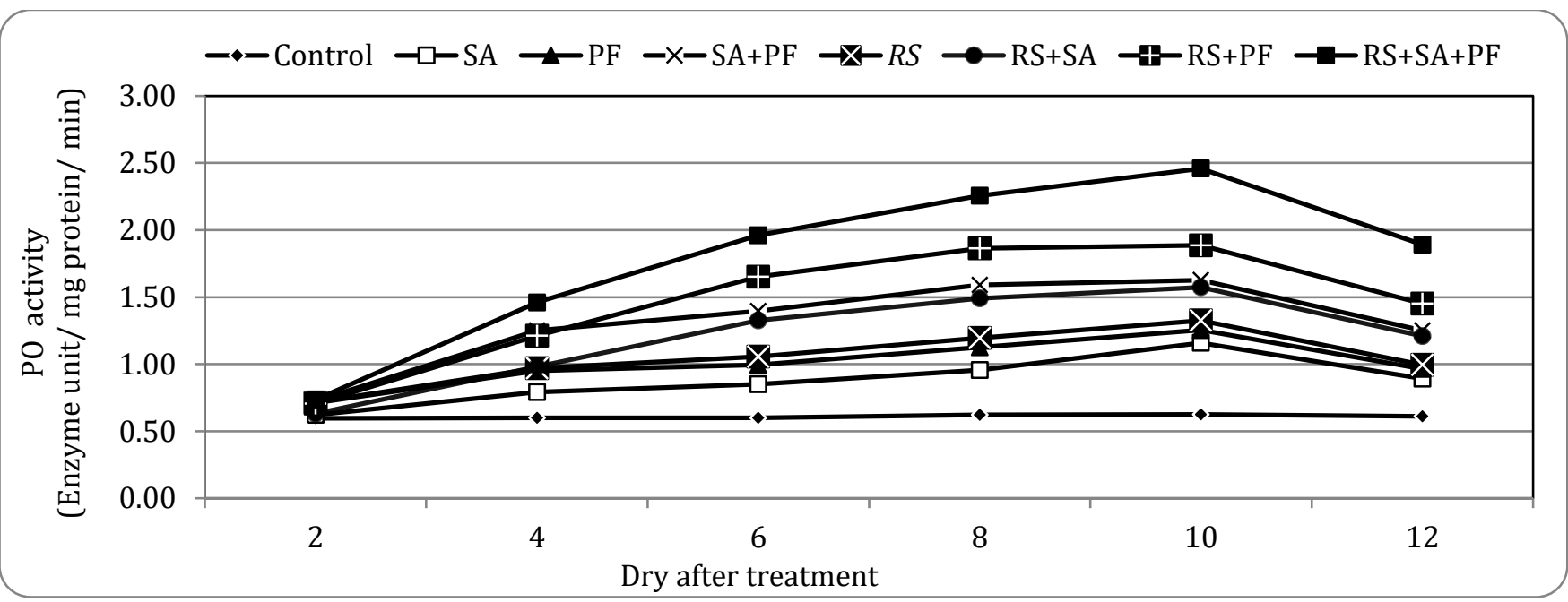

Fig. 6. Effect of SA and P. fluorescens (PF) individually and in combination on activity of peroxidase (PO) in inoculated and non-inoculated guar plants. (The samples were collected from both inoculated and non-inoculated plants after 2, 4, 6, 8, 10 and 12 days after treatment).

Polyphenol oxidase activity: In general, a significant increase in the activity of PPO was observed in both noninoculated and inoculated guar plants following treatment with SA, $P$. fluorescens and $\mathrm{SA}+P$. fluorescens more than control treatment (Figure 7). PPO accumulated more markedly in plants treated with SA, $P$. fluorescens and $\mathrm{SA}+P$. fluorescens, especially in inoculated plants and treated with combined between $P$. fluorescens and SA. Also, PPO activity increase as days after application of treatment increased until $6^{\text {th }}$ day then decreased progressively. Maximum levels of PPO were recorded at $6^{\text {th }}$ days from application of treatments, respectively in all cases. Guar plants treated with combination P. fluorescens and SA and inoculated with the pathogen recorded the highest level of PPO activity in the $6^{\text {th }}$ day from the application $(2.312$ enzyme unit $\mathrm{mg}^{-1}$ protein $\left.\mathrm{min}^{-1}\right)$ followed by $8^{\text {th }}$ of application the same treatment (2.151 enzyme unit mg${ }^{1}$ protein min $^{-1}$ ). On the other hand, PPO activity in inoculated plants increases markedly than noninoculated plants in all tested periods.

Phenylalanine ammonia lyase activity: Data in Figure 8 show that the levels of PAL activity in inoculated plants were highly increased than in non-inoculated control plants until $8^{\text {th }}$ day from inoculation then decreased approximately equal in activity in the $10^{\text {th }}$ day from inculcation. On the other hand, PAL activity was a highly significant increase in inoculated plants and treated with $P$. fluorescens and SA individually or in combination than untreated inoculated plants. Also, the activity of PAL increased by increasing time after application until 8 days from the application then the activity decreased. The higher activities of PAL were determined in the inoculated gaur plants $8^{\text {th }}$ day from treatment with $P$. fluorescens + SA followed by P. fluorescens and SA (3.745, 3.552 and 2.896 enzyme unit $\mathrm{mg}^{-1}$ protein $\mathrm{min}^{-1}$, respectively). Generally, all plants treated with $P$. fluoresces or SA either alone or in combination showed 
significant differences in the activities of PAL in guar plants extracts either inoculated or non-inoculated with $R$. solani. On the other hand, untreated and non- inoculated plants did not show any change in the pattern of PAL production.

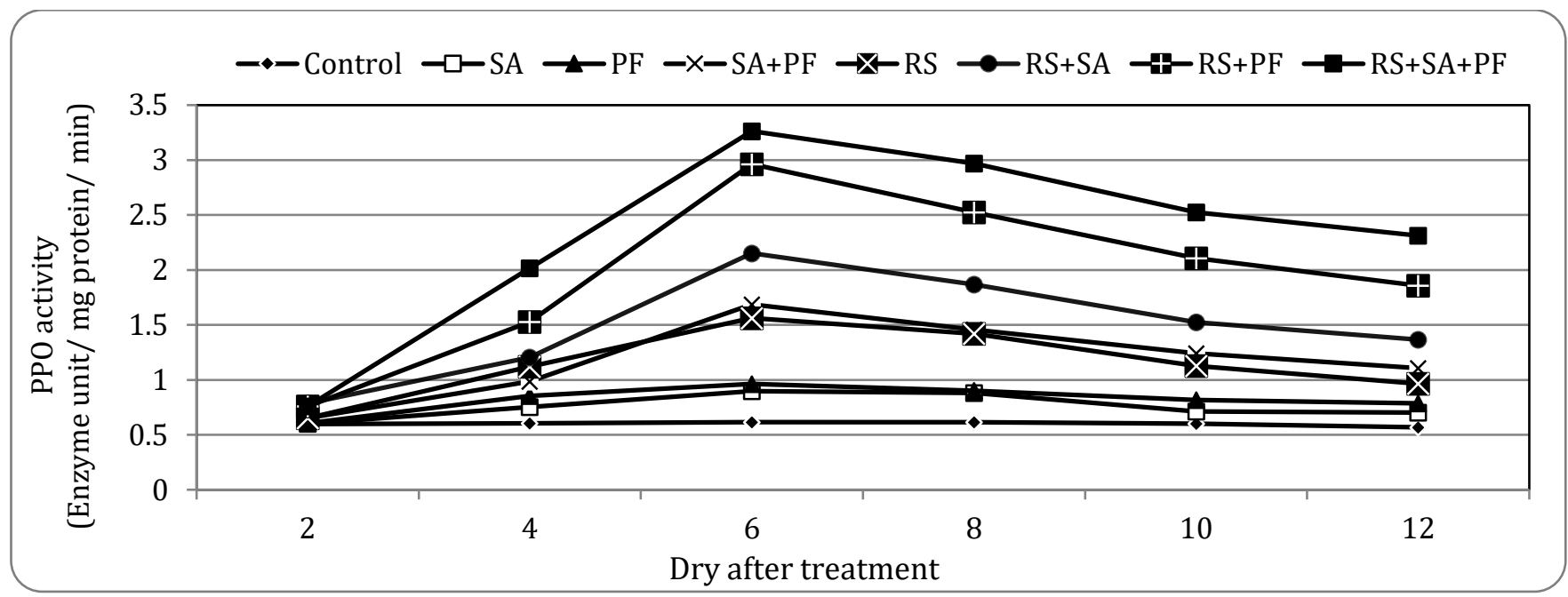

Figure 7. Effect of SA and P. fluorescens (PF) individually or in combination on the activity of polyphenol oxidase (PPO) in inoculated and non-inoculated guar plants. (The samples were collected from both inoculated and non-inoculated plants after 2, 4, 6, 8, 10 and 12 days after treatment).

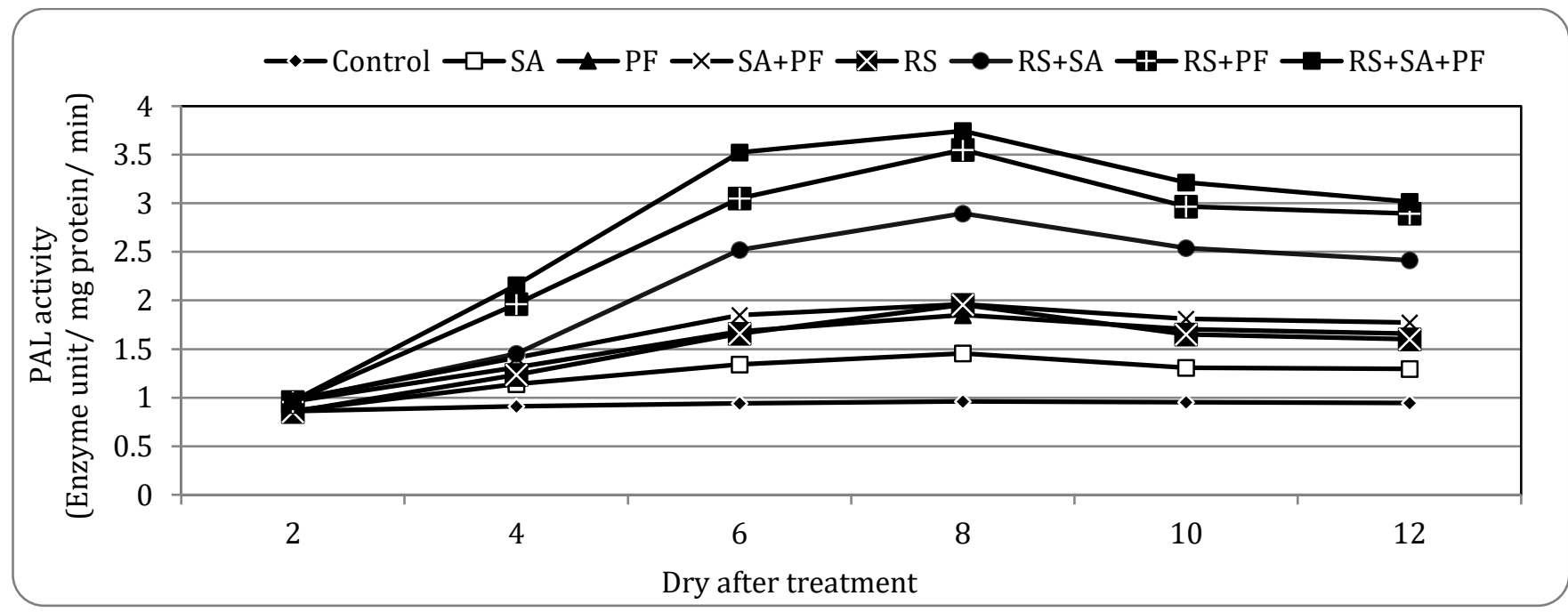

Figure 8. Effect of SA and P. fluorescens (PF) individually or in combination on the activity of phenylalanine ammonia lyase (PAL) in inoculated and non-inoculated guar plants. (The samples were collected from both inoculated and noninoculated plants after 2, 4, 6, 8, 10 and 12 days after treatment).

Chitinase activity: Data in Figure 9 indicate that all treatments have significantly increased the chitinase activity. Gaur plants treated with SA, P. fluorescens and $\mathrm{SA}+P$. fluorescens showed more activity of chitinase enzyme either inoculated or non-inoculated plants than check inoculate or non-inoculated control treatment. On the other hand, the combination between $P$. fluorescens and SA recorded the highest activity of chitinase enzyme in inoculated plants with $R$. solani after all tested periods of enzyme determination especially at 8 days after application (7.891 enzyme unit mg protein ${ }^{-1} \mathrm{~min}^{-1}$ ). The enzyme activity was increased at 2, 4, 6 and 8 days after application and then decreased at 10 days from application. 
$\boldsymbol{\beta}-\mathbf{1}, 3$ glucanase activity: Data present in Figure (10) show that there was a great increase in $\beta-1,3$ glucanase activity in all treatments either in inoculated or noninoculated plants during the examination periods compared with the control. The maximum increase in $\beta$ 1, 3 glucanase activity was recorded after 10 days in all treatment except in case of non- inoculated plants treated with SA, $P$. fluorescens individually or in combination, were recorded the maximum activity of $\beta$ -
1, 3 glucanase after 8 days from treatment. The combination between $\mathrm{SA}$ and $P$. fluorescens were recorded the highest increase of $\beta-1,3$ glucanase activity in plants inoculated with $R$. solani during the examination periods followed by inoculated plants treated with $P$. fluorescens and SA, respectively. Generally, the increase in $\beta-1,3$ glucanase activity was higher in plants inculcated with $R$. solani either treated or untreated more than non-inoculated plants.

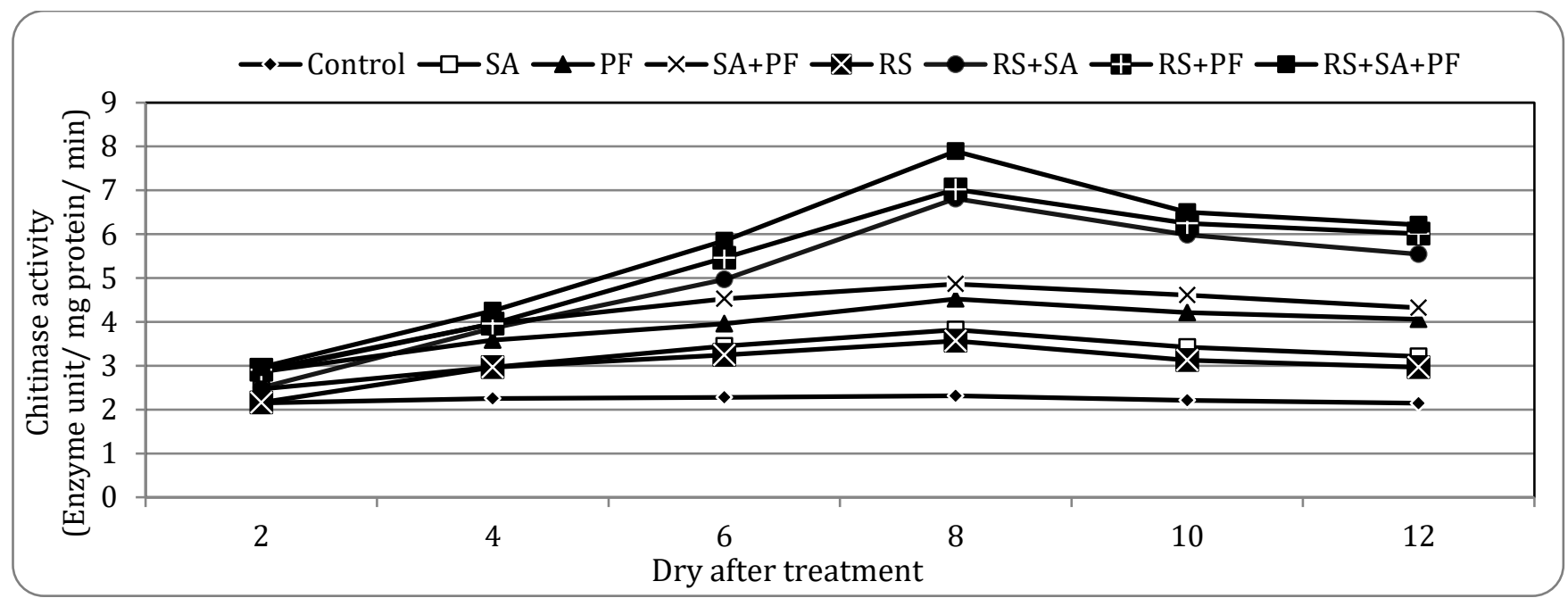

Figure 9. Effect of SA and P. fluorescens (PF) individually or in combination on the activity of chitinase in inoculated and non-inoculated guar plants. (The samples were collected from both inoculated and non-inoculated plants after 2, 4, 6, 8,10 and 12 days after treatment).

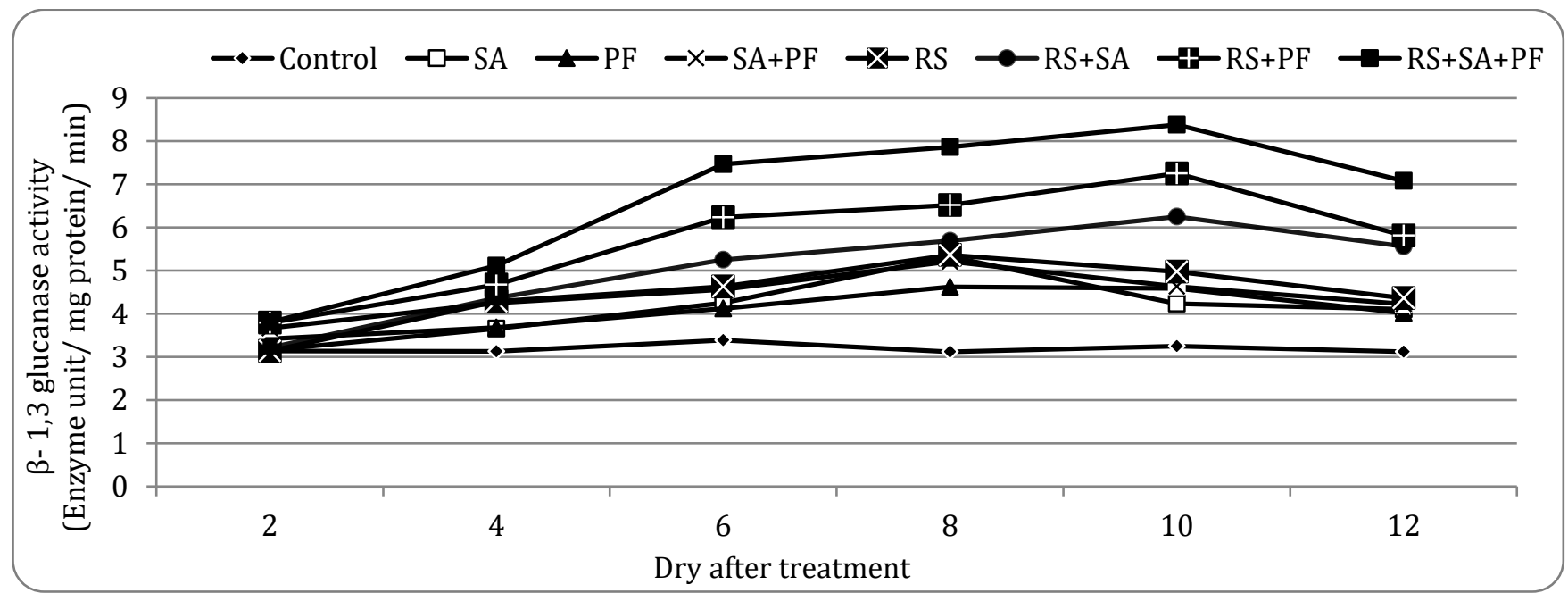

Figure10. Effect of SA and P. fluorescens (PF) individually or in combination on the activity of $\beta-1,3$ glucanase in inoculated and non-inoculated soybean plants. (The samples were collected from both inoculated and non-inoculated plants after 2, 4, 6, 8, 10 and 12 days after treatment). 
Total phenol content: The total phenols were measured in inoculated and non-inoculated guar plants treated and untreated with P. fluorescens, SA and P. fluorescens + SA (Figure 11). All treatments show significant role to the accumulation of phenolic compounds in inoculated and non-inoculated plants, whatever pre-treated gaur plants challenge inoculated with the pathogen showed a rapid increase in the accumulation of phenol compounds. Also, the accumulation of phenols in inoculated plants was highly increased than non-inoculated plants during all determination periods tested. On the other hand, the phenol contents were exhibited at $8^{\text {th }}$ day from the application in inoculated and treated plants with any treatments then decreased progressively thereafter. The maximum level of phenolic compounds were recorded at $8^{\text {th }}$ from applied of $\mathrm{SA}+P$. fluorescens treatment $(6.258 \mathrm{mg} /$ gm fresh weight) followed by the same treatment at $6^{\text {th }}$ from treatment ( $5.802 \mathrm{mg}$ / gm fresh weight).

Lignin content: Data in Figure 12 indicate that lignin content was increased in guar plants treated with $P$. fluorescence, $\mathrm{SA}$ individually or in combination either in inoculated or un-inoculated plants compared with control. Plants inoculated with $R$. solani content highly level of lignin than non-inoculated control plants.

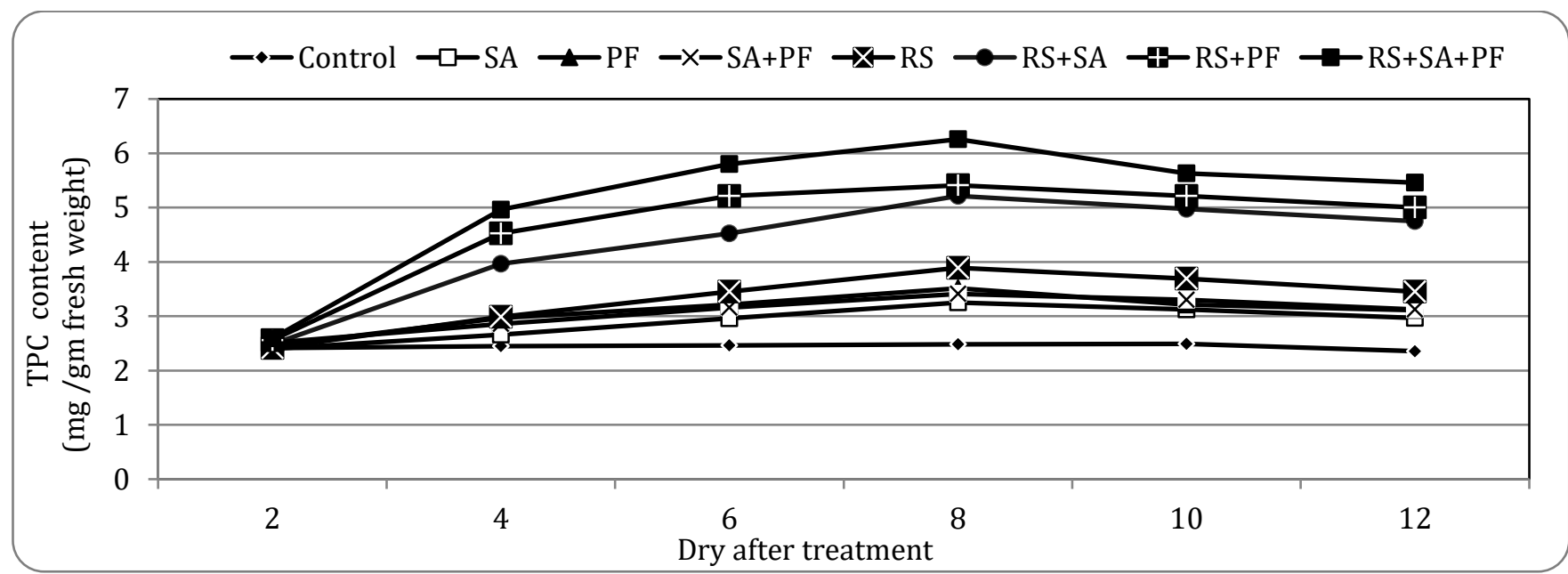

Figure 11. Effect of SA and P. fluorescens (PF) individually or in combination on total phenol content (TPC) in inoculated and non-inoculated guar plants. (The samples were collected from both inoculated and non-inoculated plants after 2, 4, 6, 8, 10 and 12 days after treatment).

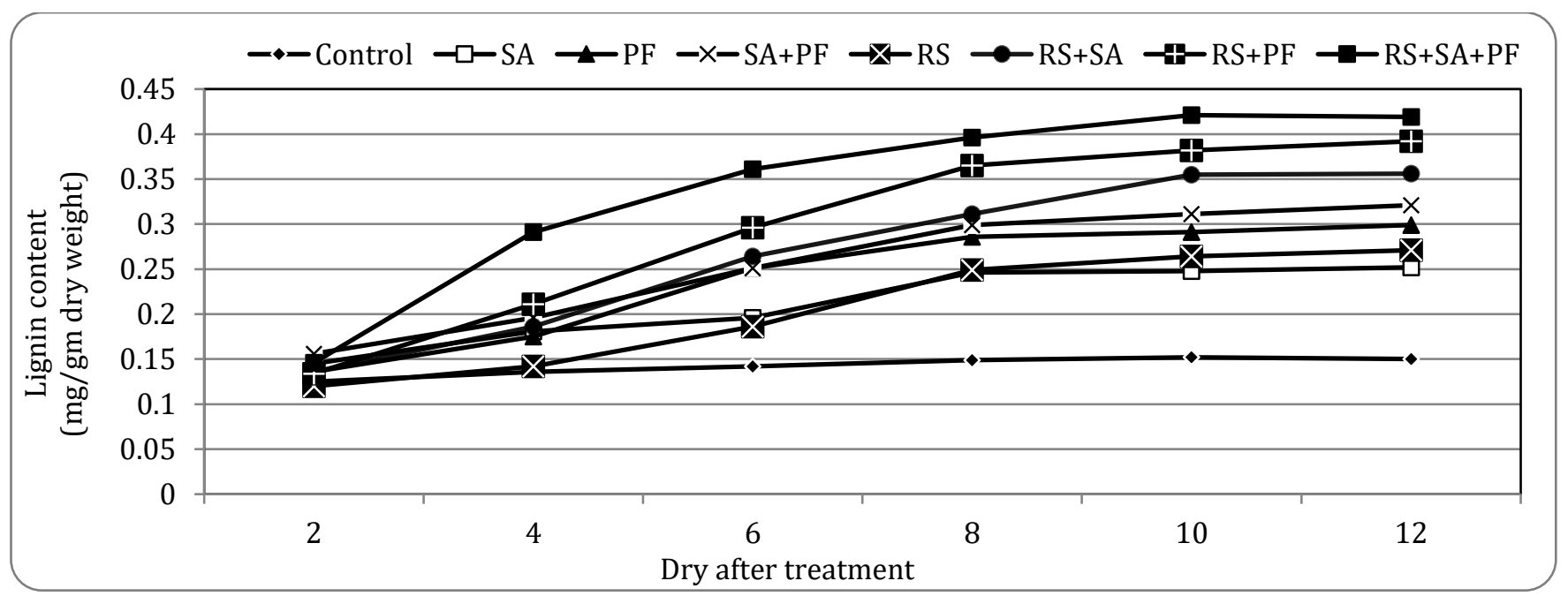

Figure 12. Effect of SA and P. fluorescens (PF) individually or in combination on lignin content in inoculated and noninoculated guar plants. (The samples were collected from both inoculated and non-inoculated plants after 2, 4, 6, 8, 10 and 12 days after treatment). 
The accumulation of lignin increased with increasing the determination periods after treatment application and/or inoculation with the pathogen until 10 days after treatment then become a slight increase at $12^{\text {th }}$ day. Plant treated with $P$. fluorescens $+\mathrm{SA}$ recorded more highly lignin content than used of $P$. fluorescens or SA individually either in inoculated or un-inoculated plants the highest lignin content was recorded by P. fluorescens + SA treatment in inoculated plant after 10 days $(0.421$ mg /gm dry weight) from application followed by $P$. fluorescens + SA treatment after 12 days $(0.419 \mathrm{mg} / \mathrm{gm}$ dry weight).

\section{DISCUSSION}

Pathogenic microorganisms cause various plant diseases that usually weaken or destroy plant tissues and reduce crop yields varying from 25-100\% (Frisvad and Samson, 1991). Root diseases are estimated to cause $10-15 \%$ yield losses annually in the world (Bajoria et al., 2008). Rhizoctonia solani Kuhn (teleomorph: Thanatephorus cucumeris (A.B. Frank). Donk is an ecologically diverse soilborne fungus that causes root rot disease on guar plants. In this study, nineteen $R$. solani isolates were isolated from guar plants collected from different fields growing in New Valley Governorate. All these isolates able attack guar plants causing damping-off and root rot diseases. These results are in agreement with those reported by Mohamed et al. (2006); Pareek and Varma (2014) and Choudhary and Sindhu (2015).

Damping-off and root rot diseases usually cannot be prevented by crop rotation or by the development of resistant crop varieties. In spite of promising results obtained by some chemical treatments in controlling damping-off and root rot, phytotoxicity and chemical residue are major problems leading to environmental pollution and human health hazards (Mandal, et al., 2009). Thus, alternative control measures for the control of damping-off and root rot should be developed. Biological control and some chemical inducers are proposed to be an effective and non-hazardous strategy to reduce crop damage caused by plant pathogens. In recent years the Pseudomonas fluorescence and salicylic acid have been extensively used for plant growth promotion and disease control.

In the present study, it was planning to investigate the possibility of minimizing the infection with damping-off and root-rot diseases of guar using SA and $P$. fluorescens individually and/or in combinations as resistance inducer. The obtained data in vitro revealed that both SA and $P$. fluorescens individually and combination caused significant reduction growth of $R$. solani. The combination between SA and P. fluorescens was more inhibited growth than used any of them individually. On the other hand, all treatments caused a significant reduction to both damping-off and root rot diseases and increased the healthy survival plants either in pots or field experiments, compared with the control. Also, these treatments improved plant growth (plant height and No. of branches plant $^{-1}$ ) and yield components (No. of pods plant ${ }^{-1}$, the weight of 100 seeds and total yield fed. ${ }^{-1}$ ) and Guaran content (gm plant ${ }^{-1}$ ) in both locations (El-Kharga and Mallawy Agric. Res. Stations) during growing season 2014. The combination of SA and P. fluorescens were recorded highly growth parameters and yield components more than from the application of either of them alone. Similar results were reported by AbdelMonaim (2013) and Choudhary and Sindhu (2015).

Induction of resistance by salicylic acid and $P$. fluorescens treatment is due to the accumulation of oxidative enzymes and pathogenesis-related proteins (PRS). These treatments cause an increase in the activity of peroxidase (PO), polyphenol oxidase (PPO) and phenylalanine ammonia lyase (PAL), chitinase, $\beta-1,3$ glucanase, the increase in such enzymes activity was correlated with increased lignin and phenolic compounds (AbdelMonaim, 2011). In this study, the obtained data indicate that guar plant treated with SA and P. fluorescens individually or combination due to accumulation of $\mathrm{PO}$, PPO, PAL and pathogenesis related protein (chitinase, $\beta$ 1, 3 glucanase) with add to increase of total phenol compounds and lignin in guar tissues either in inoculated or non-inoculated plants.

Several mechanisms have been suggested for disease control by $P$. fluorescens involving production of siderophores, HCN, ammonia, antibiotics, volatile compounds, production of hydrolytic enzymes, stimulation of phytoalexins or flavonoid-like compounds in roots, etc. or by competing with pathogens for nutrients or colonization space (Thomashow and Weller, 1996, Sarhan and Shehata, 2014). In addition, fluorescent pseudomonads can trigger a plant-mediated resistance mechanism called induced systemic resistance (ISR; Pieterse et al., 2001). Biological control of soil borne pathogens is often attributed to improved nutrition that 
boosts host defenses or to direct inhibition of pathogen growth and activity (Abdel-Monaim, 2010 and 2013).

Salicylic acid (SA) is a phenolic compound that affects a variety of biochemical and molecular events associated with induction of disease resistance. SA has been shown to play an important role in the expression of both local resistances controlled by major genes and systemic induced resistance developed after an initial pathogen attack (Hammerschmidt and Smith-Becker, 2000 and Saikia et al., 2003). Application of exogenous SA at a concentration of 1 to $5 \mathrm{mM}$ has been long known to induce pathogenesis-related (PR) gene expression and acquired resistance against a variety of microbial pathogens (Meena et al., 2001). Low concentrations (10 to $100 \mu \mathrm{M}$ ) of SA have also shown to be sufficient for pathogen-induced defense gene expression, $\mathrm{H}_{2} \mathrm{O}_{2}$ accumulation and hypersensitive cell death in plant suspension cultures (Kauss and Jeblick 1996). SA may not be a translocated primary signal for SAR, and SA may only play a regulatory role in the expression of SAR genes (Seah et al., 19S96).

In conclusion, the present study provides further evidence that may facilitate applying simple non-toxic chemicals as SA and PGPR P. fluorescens for controlling damping-off and root rot diseases in guar. Their low cost, low toxicity to the man and environmental pollution make them ideal seed soaking for diseases control under field conditions and increased seed yield and seed content from Guaran.

\section{REFERENCES}

Abdel-Monaim, M. F. 2011. Integrated management of damping-off, root and/or stem rot diseases of chickpea and efficacy of the suggested formula. Notulae Scientia Biologicae, 3: 80.

Abdel-Monaim, M. F. 2013. Improvement of Biocontrol of Damping-off and Root Rot/Wilt of Faba Bean by Salicylic Acid and Hydrogen Peroxide. Mycobiology, 41: 47.

Abdel-Monaim, M. F. and K. A. M. Abo-Elyousr. 2012. Effect of preceding and intercropping crops on suppression of lentil damping-off and root rot disease in New Valley - Egypt. Crop Protection, 32: 41-46.

Abd-El-Said, W., N. Abd-El-Ghafar and S. Shehata. 1996. Application of Salicylic acid and Aspirin for induction of resistance to tomato plants against bacterial wilt and its effect on endogenous hormones. Annals of Agricultural Science, Ain-
Shams Univ.(Egypt).

Anderson, E. 1949. Endosperm Mucilages of Legumes. Industrial \& Engineering Chemistry, 41: 28872890.

Bajoria, S., A. K. Varshney, R. P. Pareek, M. K. Mohan and P. Ghosh. 2008. Screening and characterization of antifungal clusterbean (Cyamopsis tetragonoloba) rhizobacteria. Biocontrol Science and Technology, 18: 139-156.

Biles, C. and R. Martyn. 1993. Peroxidase, Polyphenoloxidase and Shikimate dehydrognase isozymes in relation to tissue type, maturity and pathogen induction of watermelon seedling. Plant Physiolology and Biochemistry, 31: 499-506.

Bradford, M. 1976. A Rapid and Sensitive Method for the Quantitation of Microgram Quantities of Protein Utilizing the Principle of Protein-Dye Binding. Analytical Biochemistry, 72: 248-254.

Cavalcanti, F. R., M. L. V. Resende, C. P. S. Carvalho, J. A. G. Silveira and J. T. A. Oliveira. 2007. An aqueous suspension of Crinipellis perniciosa mycelium activates tomato defence responses against Xanthomonas vesicatoria. Crop Protection, 26: 729-738.

Choudhary, S. R. and S. S. Sindhu. 2015. Suppression of Rhizoctonia solani root rot disease of clusterbean (Cyamopsis tetragonoloba) and plant growth promotion by rhizosphere bacteria. Plant Pathology Journal, 14: 48.

Couillerot, O., C. Prigent-Combaret, J. Caballero-Mellado and Y. Moënne-Loccoz. 2009. Pseudomonas fluorescensand closely-related fluorescent pseudomonads as biocontrol agents of soil-borne phytopathogens. Letters in Applied Microbiology, 48: 505-512.

El-Mougy, N. S. 2002. In vitro studies on antimicrobial activity of salicylic acid and acetylsalicylic acid as pesticidal alternatives against some soilborne plant pathogens. Egypt. J. Phytopathol, 30: 41-55.

El-Mougy, N. S. 2004. Preliminary evaluation of salicylic acid and acetylsalicylic acid efficacy for controlling root rot disease of lupin under greenhouse conditions. Egypt. J. Phytopathol, 32: 11-21.

El-Sayed, W. 1996. Induction resistance to bacterial soft rot disease of potato tubers by application of Acetyl Salicylic acid, Aspirin. Annals of Agricultural Science, Ain-Shams Univ.(Egypt).

Freed, R., S. Eisensmith, S. Goetz, D. Reicosky, V. Smail and 
P. Wolberg. 1991. MSTAT-C: a software program for the design, management, and analysis of agronomic research experiments. East Lansing: Michigan State University.

Frisvad, J. and R. Samson. 1991. Filamentous fungi in foods and feeds: ecology, spoilage and mycotoxin production. Handbook of applied mycology, 3: 3168.

Gauillard, F., F. Richardforget and J. Nicolas. 1993. New Spectrophotometric Assay for Polyphenol Oxidase Activity. Analytical Biochemistry, 215: 59-65.

Gillet, J.B. 1958. Indigofera (Microcharis) in tropical Africa with related genera Cyamopsis and Rhynchotropis, Kew bulletin additional series; 1 , $165 \mathrm{p}$.

Gomez, K. A. and A. A. Gomez. 1984. Statistical procedures for agricultural research. John Wiley \& Sons.

Hammerschmidt, R., E. M. Nuckles and J. Kuć. 1982. Association of enhanced peroxidase activity with induced systemic resistance of cucumber to Colletotrichum lagenarium. Physiological Plant Pathology, 20: 73-82.

Hammerschmidt, R. and J. A. Smith-Becker. 1999. The role of salicylic acid in disease resistance. Induced Plant Defenses Against Pathogens and Herbivores: Biochemistry, Ecology and Agriculture: 37-53.

Huhndorf, S. M., B. Sneh, L. Burpee and A. Ogoshi. 1992. Identification of Rhizoctonia Species. Brittonia, 44: 338.

Kauss, H. and W. Jeblick. 1996. Influence of Salicylic Acid on the Induction of Competence for $\mathrm{H} 2 \mathrm{O} 2$ Elicitation (Comparison of Ergosterol with Other Elicitors). Plant Physiology, 111: 755-763.

Khalil, M. M. 2001. Biochemical and technological studies on the production of isolated guar protein. Nahrung/Food, 45: 21-24.

Liken, M. and A. Perdith. 1999. Fractionation of spruce trichloroacetic lignin. Acta Chin. Slov, 46: 87-97.

Liken, M. and A. Perdith. 1999. Fractionation of spruce trichloroacetic lignin. Acta Chin. Slov, 46: 87-97.

Liu, L. 1995. Induction of Systemic Resistance in Cucumber Against Fusarium Wilt by Plant GrowthPromoting Rhizobacteria. Phytopathology, 85: 695.

Mandal, S., N. Mallick and A. Mitra. 2009. Salicylic acidinduced resistance to Fusarium oxysporum f. sp. lycopersici in tomato. Plant Physiology and Biochemistry, 47: 642-649.

Marrero, N., T. Fernandez, O. Caballero, M. Rivero and M.
Lopez. 1990. Induction of antiviral factors in kidney beans var. Bolita 42. Ciencias de la Agricultura: 17-21.

Matloob, A. and K. Juber. 2013. Biological control of bean root rot disease caused by Rhizoctonia solani under green house and field conditions. Agric. Biol. JN Am, 4: 512-519.

Meena, B., T. Marimuthu and R. Velazhahan. 2001. Salicylic acid induces systemic resistance in groundnut against late leaf spot caused by Cercosporidium personatum. Journal of Mycology and Plant Pathology, 31: 139-145.

Mohamed, I., M. Bauiomy and A. Ibrahim. 2006. Efficacy of different natural products as safe management of guar damping-off disease in Egypt. Egypt. J. Phytopathol, 34: 1-15.

Montaser, F. A. M. 2011. Role of riboflavin and thiamine in induced resistance against charcoal rot disease of soybean. African Journal of Biotechnology, 10: 10842-10855.

Montaser Fawzy, A.-M. 2011. Induction of systemic resistance in soybean plants against Fusarium wilt disease by seed treatment with benzothiadiazole and humic acid. AFRICAN JOURNAL OF AGRICULTURAL RESEEARCH, 6.

Mukhtar, H. M., S. Ansari, Z. Bhat and T. Naved. 2006. Antihyperglycemic activity of Cyamopsis tetragonoloba. Beans on blood glucose levels in alloxan-induced diabetic rats. Pharmaceutical biology, 44: 10-13.

Muthomi, J. W., P. E. Otieno, G. N. C. wa, J. H. Nderitu and J. M. Wagacha. 2007. Effect of Legume Root Rot Pathogens and Fungicide Seed Treatment on Nodulation and Biomass Accumulation. Journal of Biological Sciences, 7: 1163-1170.

Pan, S. Q., X. S. Ye and J. Kuć. 1991. Association of $\beta-1,3-$ glucanase activity and isoform pattern with systemic resistance to blue mould in tobacco induced by stem injection with Peronospora tabacina or leaf inoculation with tobacco mosaic virus. Physiological and Molecular Plant Pathology, 39: 25-39.

Pareek, V. and R. Varma. 2014. Phytopathological effects and disease transmission in cluster bean seeds grown in Rajasthan. Indian J. of Plant Sci, 3: 26-30.

Pieterse, C. M. J., J. A. Van Pelt, S. C. M. Van-Wees, J. Ton, K. M. Leon-Kloosterziel, J. J. B. Keurentjes, B. W. M. Verhagen, M. Knoester, I. Van-der-Sluis, P. A. H. M. 
Bakker and L. C. Van-Loon. 2001. Rhizobacteriamediated induced systemic resistance: triggering, signalling and expression. Eur. J. Plant Pathol., 107: 51-61.

Rajkumar, M., K. J. Lee and H. Freitas. 2008. Effects of chitin and salicylic acid on biological control activity of Pseudomonas spp. against damping off of pepper. South African Journal of Botany, 74: 268273.

Rajkumar, M., W. H. Lee and K. J. Lee. 2005. Screening of bacterial antagonists for biological control ofPhytophthora blight of pepper. Journal of Basic Microbiology, 45: 55-63.

Saikia, R., T. Singh, R. Kumar, J. Srivastava, A. K. Srivastava, K. Singh and D. K. Arora. 2003. Role of salicylic acid in systemic resistance induced by Pseudomonas fluorescens against Fusarium oxysporum f. sp. ciceri in chickpea. Microbiological Research, 158: 203-213.

Saikia, R., M. Yadav, S. Varghese, B. P. Singh, D. K. Gogoi, R. Kumar and D. K. Arora. 2006. Role of Riboflavin in Induced Resistance against Fusarium Wilt and Charcoal Rot Diseases of Chickpea. The Plant Pathology Journal, 22: 339-347.

Sarhan, E. A. D. and H. S. Shehata. 2014. Potential Plant Growth-promoting Activity of Pseudomonas spp. and Bacillus spp. as Biocontrol Agents Against Dampingoff in Alfalfa. Plant Pathology Journal, 13: 8-17.

Seah, S., K. Sivasithamparam and D. W. Turner. 1996. The Effect of Salicylic Acid on Resistance in Wheat (Triticum aestivum) Seedling Roots Against the Take-All Fungus, Gaeumannomyces graminis var tritici. Australian Journal of Botany, 44: 499.

Tabarraei, M., J. Amini and B. Harighi. 2011. Effects of'fluorescent Pseudomonads' for control of damping-off disease of cantaloupe caused by'Phytophthora drechsleri'. Australian Journal of Crop Science, 5: 1427.

Thomashow, L. S. and D. M. Weller. 1996. Current Concepts in the Use of Introduced Bacteria for Biological Disease Control: Mechanisms and Antifungal Metabolites. Plant-Microbe Interactions. Springer US, pp. 187-235.

Undersander, D., D. Putnam, A. Kaminski, K. Kelling, J. Doll, E. Oplinger and J. Gunsolus. 2006. Alternative Field Crops Manual, University of Wisconsin-Madison.

Urbanek, H., E. Kuzniak-Gebarowska and K. Herka. 1991. Elicitation of defence responses in bean leaves by Botrytis cinerea polygalacturonase. Acta Physiologiae Plantarum (Poland).

Wang, M. L. and J. B. Morris. 2007. Flavonoid content in seeds of guar germplasm using HPLC. Plant Genetic Resources: Characterization and Utilization, 5: 9699.

Wirth, S. J. and G. A. Wolf. 1992. Micro-plate colourimetric assay for Endo -acting cellulase, xylanase, chitinase, 1,3- $\beta$-glucanase and amylase extracted from forest soil horizons. Soil Biology and Biochemistry, 24: 511-519.

Yoshida, S., S. Hiradate, T. Tsukamoto, K. Hatakeda and A. Shirata. 2001. Antimicrobial Activity of Culture Filtrate of Bacillus amyloliquefaciensRC-2 Isolated from Mulberry Leaves. Phytopathology, 91: 181187. 